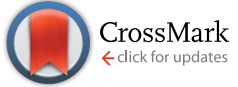

Cite this: RSC Adv., 2016, 6, 110235

\title{
Dimethyl carbonate synthesis from carbon dioxide using ceria-zirconia catalysts prepared using a templating method: characterization, parametric optimization and chemical equilibrium modeling $\dagger$
}

\author{
Praveen Kumar, ${ }^{\text {ab }}$ Patrick With, ${ }^{\text {bc }}$ Vimal Chandra Srivastava, ${ }^{* a}$ Kartikeya Shukla, ${ }^{a}$ \\ Roger Gläser ${ }^{\mathrm{b}}$ and Indra Mani Mishra ${ }^{\text {ad }}$
}

\begin{abstract}
In this paper, a series of $\mathrm{Ce}_{x} \mathrm{Zr}_{1-x} \mathrm{O}_{2}$ solid solution spheres were synthesized by exo- and endo-templating methods and tested for dimethyl carbonate (DMC) synthesis using direct conversion of $\mathrm{CO}_{2}$. The synthesized catalysts were characterized by $\mathrm{X}$-ray diffraction (XRD), $\mathrm{N}_{2}$-physisorption, scanning electron microscopy (SEM), and $\mathrm{CO}_{2} / \mathrm{NH}_{3}$-temperature-programmed desorption (TPD). Formation of $\mathrm{Ce}_{x} \mathrm{Zr}_{1-x} \mathrm{O}_{2}$ solid solutions with tetragonal and cubic crystal structures depending on cerium/zirconium compositions was confirmed by XRD analysis. The specific surface area of the mixed oxide decreased and the average pore diameter increased with an increase in the ceria content, with the exception of the mixed oxides with $x=0.4-0.5$ i.e. $\mathrm{Ce}_{0.4} \mathrm{Zr}_{0.6} \mathrm{O}_{2}$ and $\mathrm{Ce}_{0.5} \mathrm{Zr}_{0.5} \mathrm{O}_{2}$. The basic and acidic site density of the synthesized catalysts was in the order: $\mathrm{ZrO}_{2}<\mathrm{CeO}_{2}<\mathrm{Ce}_{0.5} \mathrm{Zr}_{0.5} \mathrm{O}_{2}$, and the basic and acidic site density per unit area followed the same order. The best $\mathrm{Ce}_{0.5} \mathrm{Zr}_{0.5} \mathrm{O}_{2}$ catalyst was further used for the optimization of reaction conditions such as reaction time, reaction temperature, catalyst dose and reusability for DMC synthesis. Furthermore, study of chemical equilibrium modeling was done using the Peng-Robinson-Stryjek-Vera equation of state (PRSV-EOS) along with the van der Waals one-fluid reaction condition so as to calculate change of Gibbs free energy $\left(\Delta G^{\circ}\right)$ and heat of reaction $\left(\Delta H^{\circ}\right)$.
\end{abstract}

Received 10th September 2016 Accepted 3rd November 2016

DOI: $10.1039 / c 6 r a 22643 d$

www.rsc.org/advances excellent biodegradability, high versatility and bioaccumulation. DMC is also used as a fuel additive as an octane enhancer due to the fact that its oxygen content is three times higher than that of methyl tertiary butyl ether (MTBE).,4

Various traditional and developing methods are used for the synthesis of DMC. The methanol oxidative carbonylation, methylnitrite carbonylation and phosgenation processes are full-scale commercial methods used for the DMC synthesis. ${ }^{2,5-9}$ Phosgenation process is now abandoned because of the hazards associated with it. Transesterification of ethylene carbonate and urea with methanol and conversion of $\mathrm{CO}_{2}$ are in the developing stage for the synthesis of DMC. Consequently, direct $\mathrm{CO}_{2}$ conversion reaction is being developed for its industrial feasibility. It is the most desired method for the synthesis of DMC due to its environment-friendly nature, associated green chemistry, low cost and easy availability of the materials., ${ }^{\mathbf{2 1 0 - 1 2}}$ However, this method has difficulties such as activation of methanol/ $\mathrm{CO}_{2}$ and chemical equilibrium. ${ }^{13}$ To overcome these problems, it is essential to develop effective catalysts which can relax chemical equilibrium and help in activation of methanol/ $\mathrm{CO}_{2}{ }^{14}$

Various homogeneous and heterogeneous catalysts have been studied for increasing the DMC yield during conversion of $\mathrm{CO}_{2}$ with methanol to produce DMC. ${ }^{15-17}$ On the other hand,

$\dagger$ Electronic supplementary information (ESI) available. See DOI: $10.1039 / \mathrm{c} 6 \mathrm{ra} 22643 \mathrm{~d}$ 
some acidic compounds such as phosphoric acid $\mathrm{H}_{3} \mathrm{PO}_{4}-\mathrm{ZrO}_{2}$ or $\mathrm{H}_{3} \mathrm{PW}_{12} \mathrm{O}_{4}-\mathrm{ZrO}_{2},{ }^{18}$ and $\mathrm{ZrO}_{2}-\mathrm{KCl} ;{ }^{19}$ active metal catalysts such as zirconium oxide $\left(\mathrm{ZrO}_{2}\right),{ }^{20}$ cerium oxide $\left(\mathrm{CeO}_{2}\right),{ }^{20,21}$ copper nickel/graphite, ${ }^{22} \mathrm{Cu}-\mathrm{Fe},{ }^{23} \mathrm{Ce}_{0.5} \mathrm{Zr}_{0.5} \mathrm{O}_{2},{ }^{24,25}$ metal oxide/ $\mathrm{Ce}_{0.6} \mathrm{Zr}_{0.4} \mathrm{O}_{2},{ }^{26} \mathrm{Al}_{2} \mathrm{O}_{3}-\mathrm{CeO}_{2},{ }^{27} \mathrm{ZrO}_{2}-\mathrm{MgO},{ }^{28} \mathrm{SnO}_{2} / \mathrm{SiO}_{2},{ }^{29} \mathrm{ZrO}_{2} /$ $\mathrm{SiO}_{2},{ }^{29}$ and $\mathrm{Cu}_{1.5} \mathrm{PMo}_{12} \mathrm{O}_{40},{ }^{30}$ basic compounds such as $\mathrm{KOH},{ }^{31}$ $\mathrm{K}_{2} \mathrm{CO}_{3},{ }^{31}$ and $\mathrm{CH}_{3} \mathrm{OK} ;{ }^{31}$ heteropoly acids $\mathrm{H}_{3} \mathrm{PW}_{12} \mathrm{O}_{4} / \mathrm{Ce}_{x} \mathrm{Zr}_{1-x^{-}}$ $\mathrm{O}_{2},{ }^{32} \mathrm{H}_{3} \mathrm{PW}_{12} \mathrm{O}_{40} / \mathrm{Ce}_{x} \mathrm{Ti}_{1-x} \mathrm{O}_{2}$ heteropolyoxometalates, ${ }^{33}$ etc. have been used as catalysts for DMC synthesis from $\mathrm{CO}_{2} \cdot{ }^{34,35} \mathrm{Among}$ these catalysts, acid-base bi-functional catalysts have been found more effective at different pressure and temperature. However, most of these studies were conducted with only aim for catalyst preparation, characterization and preliminary testing. Studies on important chemical engineering aspects such as chemical equilibrium and thermodynamic analysis are scarce.

In the prthe esent study, composition of cerium-zirconium mixed oxide as well as the operating conditions for the reaction have been optimized. The synthesis of $\mathrm{Ce}_{x} \mathrm{Zr}_{1-x} \mathrm{O}_{2}$ mixed oxide spheres was carried out using exo- and endo-templating method. The synthesized catalysts were characterized by X-ray diffraction (XRD), $\mathrm{N}_{2}$-sorption, scanning electron microscopy (SEM) and $\mathrm{CO}_{2}$ - and $\mathrm{NH}_{3}$-temperature-programmed desorption (TPD). The optimum catalyst was further used under constant pressure for optimizing reaction conditions such as reaction time, reaction temperature and catalyst dose. Reusability of the catalyst was also studied. Further, chemical equilibrium modeling was done using Peng-Robinson-Stryjek-Vera equation of state (PRSV-EoS) along with the van der Waals one-fluid reaction condition so as to calculate Gibbs free energy change $\left(\Delta G_{\mathrm{r}}^{\circ}\right)$ and the heat of reaction $\left(\Delta H_{\mathrm{r}}^{\circ}\right)$.

\section{Experimental}

\section{Materials}

Dimethyl carbonate $\left(\left(\mathrm{CH}_{3} \mathrm{O}\right)_{2} \mathrm{CO}\right) \geq 99 \%$, methanol $99.0 \%$, zirconium(Iv) oxychloride octahydrate $\left(\mathrm{ZrOCl}_{2} \cdot 8 \mathrm{H}_{2} \mathrm{O}\right) 99.0 \%$ and cerium(III) nitrate hexahydrate $\left(\mathrm{Ce}\left(\mathrm{NO}_{3}\right)_{3} \cdot 6 \mathrm{H}_{2} \mathrm{O}\right) 99.0 \%$, were purchased from Sigma Aldrich Chemicals, $\mathrm{GmbH}$. Ammonia solution $\left(25 \mathrm{wt} \%\right.$ in $\left.\mathrm{H}_{2} \mathrm{O}\right)$ and nitric acid $\left(65 \mathrm{wt} \%\right.$ in $\left.\mathrm{H}_{2} \mathrm{O}\right)$ were purchased from Merck $\mathrm{GmbH}$. Carbon spheres were kindly supplied from Blücher $\mathrm{GmbH}$ (Brunauer-Emmett-Teller surface area $=1748 \mathrm{~m}^{2} \mathrm{~g}^{-1} ;$ Barrett-Joyner-Halenda volume $=2 \mathrm{~cm}^{3} \mathrm{~g}^{-1}$; diameter $=0.45-0.5 \mathrm{~mm}$ ), whereas Pluronic F-127 was purchased from BASF, Germany. All chemicals used were of analytical grade.

\section{Catalyst preparation}

Cerium-zirconium mixed oxide catalysts with different $\mathrm{Ce}_{x} \mathrm{Zr}_{1-x} \mathrm{O}_{2}(x=0$ to 1$)$ molar ratios were synthesized using exoand endo-templating method. For this, $\mathrm{Ce}\left(\mathrm{NO}_{3}\right)_{2}$ and $\mathrm{Zr}\left(\mathrm{NO}_{3}\right)_{3}$ were dissolved separately in $100 \mathrm{~mL}$ in double-distilled water and were further mixed together in the desired molar proportion $\mathrm{Ce}_{x} \mathrm{Zr}_{1-x} \mathrm{O}_{2}(x=0$ to 1$)$ under continuous stirring at room temperature. Liquid ammonia solution was added drop-by-drop to the precursor solution over a period of $0.5 \mathrm{~h}$ until the $\mathrm{pH}$ reached $\sim 9.5$ and a white/light yellow precipitate was formed.
The mixture was aged for $2 \mathrm{~h}$ under continuous stirring, and thereafter it was filtered. The precipitate retained on the filter was washed with double-distilled water until the $\mathrm{pH}$ of the filtrate became neutral. Finally, the filter cake was transferred to a $200 \mathrm{~mL}$ polypropylene (PP) bottle and double-distilled water was added to it until the total weight of the mixture became $30 \mathrm{~g}$. Thereafter, $2.5 \mathrm{~mL} \mathrm{HNO}_{3}\left(65 \mathrm{wt} \%\right.$ in $\left.\mathrm{H}_{2} \mathrm{O}\right)$ was added to the mixture. The PP-bottle was transferred to an ultrasonic bath (Sonorex RK1, Fa. Bandelin) where it was kept for $4 \mathrm{~h}$ until a clear sol was formed. Pluronic F-127 as triblock copolymer (TBC) was added such that the molar ratios of TBC to cerium along with zirconium $\left(n_{\mathrm{TBC}} / n_{\mathrm{Ce}+\mathrm{Zr}}\right)$ become 0.017 . This ratio was the optimum to the sol as an endo-template. ${ }^{36,37}$ This mixture was again kept in the ultrasonic bath for $3 \mathrm{~h}$ for dissolving the Pluronic F-127. $4.42 \mathrm{~g}$ preactivated (for $24 \mathrm{~h}$ at $110^{\circ} \mathrm{C}$ ) polymerbased spherical activated carbon (PBSAC) was added to the nanoparticle sol and was further dried at $50{ }^{\circ} \mathrm{C}$ for $12 \mathrm{~h}$. The prepared catalyst was activated at $600{ }^{\circ} \mathrm{C}$ for $5 \mathrm{~h}$ under air flow $\left(40 \mathrm{~cm}^{3} \mathrm{~min}^{-1}\right.$ ) with heating rate of $3{ }^{\circ} \mathrm{C} \mathrm{min}^{-1}$ from room temperature to $600{ }^{\circ} \mathrm{C}$ with a holding time of $1 \mathrm{~h}$ at $100{ }^{\circ} \mathrm{C}$ and $5 \mathrm{~h}$ at $600{ }^{\circ} \mathrm{C}$. After calcination, light yellow $\mathrm{Ce}_{x} \mathrm{Zr}_{1-x} \mathrm{O}_{2}$ mixed oxide spheres were obtained. For characterization and catalytic experiments, $\mathrm{Ce}_{x} \mathrm{Zr}_{1-x} \mathrm{O}_{2}$ mixed oxides were sieved to obtain the spheres in the size range of $0.2-0.4 \mathrm{~mm}$.

\section{Catalyst characterization}

XRD was used to study the molecular structure, atoms and crystalline nature. For this purpose, samples were crushed with a mortar before testing. X-ray diffractograms (Bruker AXS, Germany) at $40 \mathrm{kV} / 30 \mathrm{~mA}$ with $\mathrm{CuK} \alpha$ radiation $(\lambda=1.5406 \AA)$ 0.02 step size over $2 \theta$ scan range $5 \leq 2 \theta \leq 100^{\circ}$ were obtained. PANalytical X'pert high score was used for the identification of crystalline phase with International Centre for Diffraction Data (ICDD) database. $\mathrm{N}_{2}$ sorption isotherms utilize the principle of physical adsorption to get the information about BET surface area, pore volume and pore size distribution of the solid materials. Textural properties were estimated using $\mathrm{N}_{2}$ sorption measurements at $-197{ }^{\circ} \mathrm{C}$ (Micromeritics ASAP 2020). BET isotherm was used for calculating the surface area of the porous material by physical adsorption of $\mathrm{N}_{2}$ gas at its boiling temperature. TPD was used to study the binding interaction of adsorbate $\mathrm{CO}_{2}$ or $\mathrm{NH}_{3}$ on the catalyst surface and to provide the information regarding the adsorbate bound on the surface. It is known that the high temperature desorption peak has stronger bonding of the adsorbates on the catalyst surface. In the TPD study, initially a sample is saturated with the reactant gas, and then physisorbed fraction of the reactant gas is desorbed with the help of an inert gas such as helium. After that the temperature of the sample is increased linearly at a particular heating rate. During this process, an inert carrier gas is passed through the sample at a particular flow rate. The amount of the desorbed $\mathrm{CO}_{2}$ or $\mathrm{NH}_{3}$ is quantified with the help of a thermal conductivity detector (TCD). Acidic and basic nature of the synthesized catalyst was determined by the TPD (Micromeritics Chemisorb 2720) of $\mathrm{NH}_{3}$ and $\mathrm{CO}_{2}$, respectively. To investigate the morphology of the synthesized catalysts, scanning electron 
microscope (SEM) were used. Elemental composition and morphology of the cerium/zirconium synthesized materials was investigated by quanta 200 FEG (FEI Netherlands). Initially, the prepared sample was spread on the sample holder and then the samples were gold-coated using sputter coater (Edwards S150) to increase the conductivity of the preliminary materials. After that, the prepared samples were used for taking image using FESEM at $20 \mathrm{kV}$ under vacuum. Thereafter, the energy-dispersive X-ray spectroscopy (EDX) was carried out to find out the metal content of the sample. Elemental mapping was used for understanding the metal distribution in the prepared catalysts. Metal loading on the catalysts was determined by AAS and ICPOES. For determining the elemental ratio of the catalysts, $1.0 \mathrm{~g}$ of the catalyst was soaked in $10 \mathrm{~mL} 65 \%$ nitric acid for $24 \mathrm{~h}$ at room temperature so as to dissolve the metals from the catalysts. The solutions were filtered and the filtrate was used for the determination of the metal concentration by AAS (Avanta M by GBC Scientific Equipment Pvt Ltd.). ICP-OES supplied by OPTIMA 8000 von Perkin Elmer was also used for determining the amount of metals dispersed on the catalysts. For sample preparation, the sample $(50.0 \pm 0.1)$ was dissolved by a microwave assisted digestion (Multiwave 3000 from Anton Paar) using $2 \mathrm{~mL}$ HF (48 wt\%, Suprapur, Merck), $2 \mathrm{~mL} \mathrm{HNO}_{3}$ (69 wt\%, Supra, Roth), $2 \mathrm{~mL} \mathrm{HCl} \mathrm{(35} \mathrm{wt \% ,} \mathrm{Supra,} \mathrm{Roth)} \mathrm{and} 3 \mathrm{~mL} \mathrm{H}_{2} \mathrm{SO}_{4}$ (85 wt\%, Suprapur, Merck). Microwave conditions were: 1100 watt per ramp for $20 \mathrm{~min}$, hold for $30 \mathrm{~min}$ and cooled for $15 \mathrm{~min}$. After the microwave digestion, $12 \mathrm{~mL} \mathrm{H}_{3} \mathrm{BO}_{4}$ (for complexation of $\mathrm{HF}$ ) and $1 \mathrm{~mL} \mathrm{HlO}_{4}$ were added. Afterwards, the sample was digested for a second time using microwave conditions as used earlier. After the microwave treatment, $\mathrm{H}_{2} \mathrm{O}$ was added until a volume of $50 \mathrm{~mL}$ was obtained. The eight samples were prepared as known concentration for preparation of the calibration curve. Concentration of the unknown solution was estimated using this calibration curve.

\section{Catalytic activity}

Catalytic conversion of $\mathrm{CO}_{2}$ with methanol to produce DMC was performed in the reaction autoclave (i.e. batch reactor) made by Berghof, Germany (Model-BHL-800). A magnetic stirrer was used to make the reactant mixture homogeneous during the reaction. A rubber made O-ring was used in between the reaction autoclave and the head of the instrument panel to bind them smoothly and to make the reaction chamber air tight. Initially, the reactor was filled with the required amount of methanol and the catalysts. The reactor was heated to the reaction temperature $\left(100-180^{\circ} \mathrm{C}\right)$ and pressurized with $\mathrm{CO}_{2}$ up to a pressure of 150 bar and maintained for $6-48 \mathrm{~h}$ for the reaction to proceed. After $(6-48 \mathrm{~h})$, the reactor was cooled down so that the product mixture is brought to at $<-20^{\circ} \mathrm{C}$ by using an ice bath, and thereafter, centrifugation was used for removing catalyst from the product mixture. All the reactions were studied in the presence of activated molecular sieve $3 \mathrm{~A}$ as a dehydrating agent and at a constant stirrer speed of 600 revolutions per min. Catalyst was washed with methanol and dried at $150{ }^{\circ} \mathrm{C}$ for $12 \mathrm{~h}$ and then was activated at $500{ }^{\circ} \mathrm{C}$ for $4 \mathrm{~h}$ after each cycle. Similarly, molecular sieve was activated at $240^{\circ} \mathrm{C}$ for $4 \mathrm{~h}$ after each cycle.

\section{Results and discussion}

\section{Catalyst characterization}

X-ray diffraction. XRD profiles of $\mathrm{Ce}_{x} \mathrm{Zr}_{1-x} \mathrm{O}_{2}(x=0$ to 1$)$ catalysts are given in Fig. 1a. No separate peak is found in the cerium-zirconium mixed oxide. Pure zirconia $(x=0)$ tetragonal phase showed the characteristic (111) reflection at $2 \theta=30^{\circ}$. With an increase in ceria amount, the reflex at $2 \theta=30^{\circ}$ shifted

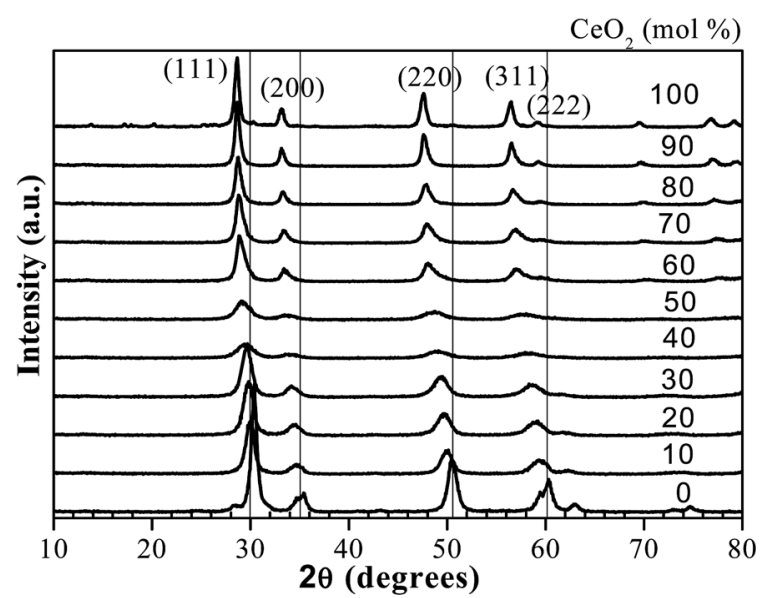

(a)

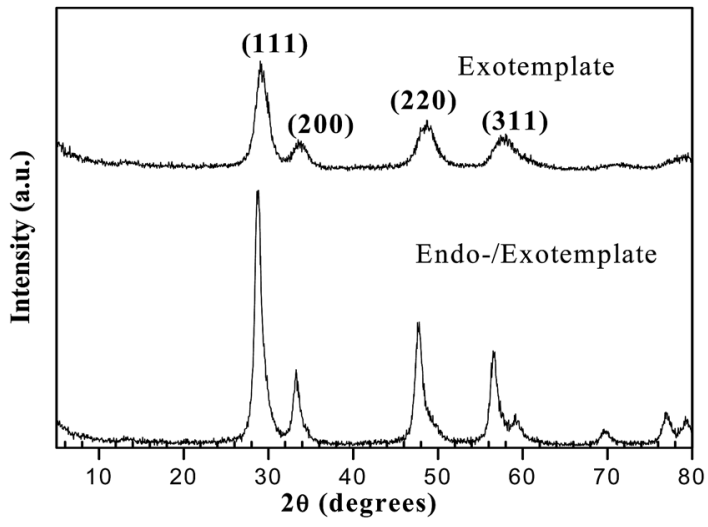

(b)

Fig. 1 (a) XRD patterns $\mathrm{Ce}_{x} \mathrm{Zr}_{1-x} \mathrm{O}_{2}(x=0$ to 1 ) with exotemplate, (b) XRD patterns of the $\mathrm{Ce}_{0.5} \mathrm{Zr}_{0.5} \mathrm{O}_{2}$ with exotemplate and endo-/exotemplate $\left(n_{\mathrm{TBC}} / n_{\mathrm{Ce}+\mathrm{Zr}}=0.017\right)$

Table $1 \mathrm{~N}_{2}$ sorption of cerium-zirconium mixed oxides catalysts

\begin{tabular}{llll}
\hline & $\begin{array}{l}\text { BET surface area } \\
\left(\mathrm{m}^{2} \mathrm{~g}^{-1}\right)\end{array}$ & $\begin{array}{l}\text { Pore volume } \\
\left(\mathrm{Cm}^{3} \mathrm{~g}^{-1}\right)\end{array}$ & $\begin{array}{l}\text { Pore diameter } \\
(\mathrm{nm})\end{array}$ \\
\hline$x=0.0$ & 112 & 0.42 & 15.4 \\
$x=0.1$ & 81 & 0.42 & 21.5 \\
$x=0.2$ & 69 & 0.43 & 22.9 \\
$x=0.3$ & 71 & 0.47 & 24.3 \\
$x=0.4$ & 121 & 0.33 & 10.0 \\
$x=0.5$ & 123 & 0.40 & 11.9 \\
$x=0.6$ & 59 & 0.39 & 24.8 \\
$x=0.7$ & 54 & 0.35 & 28.7 \\
$x=0.8$ & 49 & 0.36 & 30.1 \\
$x=0.9$ & 31 & 0.21 & 30.6 \\
$x=1.0$ & 28 & 0.20 & 30.4
\end{tabular}


towards lower $2 \theta$ values. For pure ceria, a major peak at $2 \theta=28^{\circ}$ was observed, which is typical of the cubic fluorite structure of ceria. ${ }^{38-40}$ For ceria content of $60 \mathrm{~mol} \%$, the crystal structure was tetragonal. The two peaks at $2 \theta=29^{\circ}$ and $35^{\circ}$ for the two samples of $\mathrm{Ce}_{0.4} \mathrm{Zr}_{0.6} \mathrm{O}_{2}$ and $\mathrm{Ce}_{0.5} \mathrm{Zr}_{0.5} \mathrm{O}_{2}$ showed much lower intensity than that for other mixed oxides with tetragonal and cubic crystal structures. This is because of the crystallite formation for the samples having cerium/zirconium in the molar ratio $\approx 1 .^{41}$ This would explain the sudden increase in the specific surface area of these two samples. XRD of $\mathrm{Ce}_{0.5} \mathrm{Zr}_{0.5} \mathrm{O}_{2}$ synthesized using exotemplate and endo-/exo-template method $\left(n_{\mathrm{TBC}} / n_{\mathrm{Ce}+\mathrm{Zr}}=0.017\right)$ is shown in Fig. $1 \mathrm{~b}$. It may be seen that the reflexes of $\mathrm{Ce}_{0.5} \mathrm{Zr}_{0.5} \mathrm{O}_{2}$, synthesized with endo-/exo-template are more intense than that with exo-template. This suggests that in the presence of larger particles, endo-templates arise. This hypothesis is supported by the lower values of the specific surface and the specific pore volume (Table 1). At the same time, the mean pore diameter is larger. Substitution of metals in the crystal lattice increases the oxygen vacancies which in turn help in increasing the reactive catalytic sites. ${ }^{42,43}$ Also, the cations of octahedral sites help in generation of other active/intermediate species via conjugation of redox pairs. ${ }^{44}$ High catalytic activity in these doped catalysts is due to improved electron transfer mechanism and due to more oxygen vacancies. ${ }^{45,46}$ The $\mathrm{ZrO}_{2}$ incorporation in $\mathrm{CeO}_{2}$ improves the thermal resistance and more importantly the redox capacity of $\mathrm{CeO}_{2}-\mathrm{ZrO}_{2}$ mixed metal oxide. As $\mathrm{Ce}^{4+}(1.01 \AA)$ has a larger ionic radius than $\mathrm{Zr}^{4+}$ $(0.80 \AA)$, shrinkage of the lattice due to the replacement of $\mathrm{Ce}^{4+}$ with $\mathrm{Zr}^{4+}$ affects the lattice structure. This lowers the energy for $\mathrm{Ce}^{4+}$ reduction and enhances the $\mathrm{CeO}_{2}$ reducibility. ${ }^{47-49}$

Surface morphology and elemental analysis. SEM micrographs (Fig. 2) of $\mathrm{CeO}_{2}, \mathrm{ZrO}_{2}$ and $\mathrm{Ce}_{0.5} \mathrm{Zr}_{0.5} \mathrm{O}_{2}$ with particles size

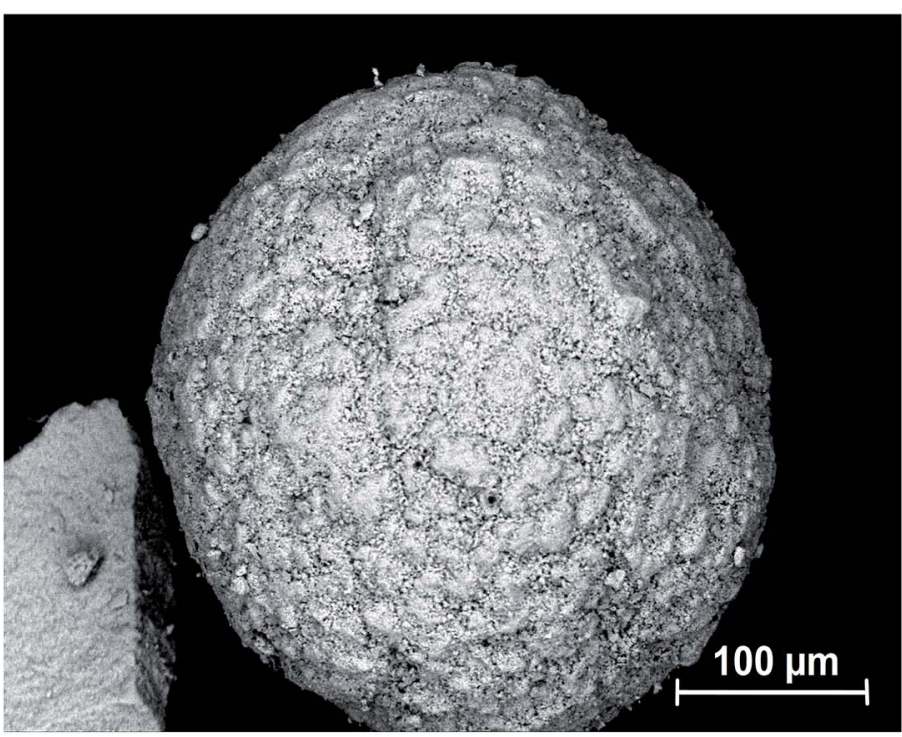

(a)

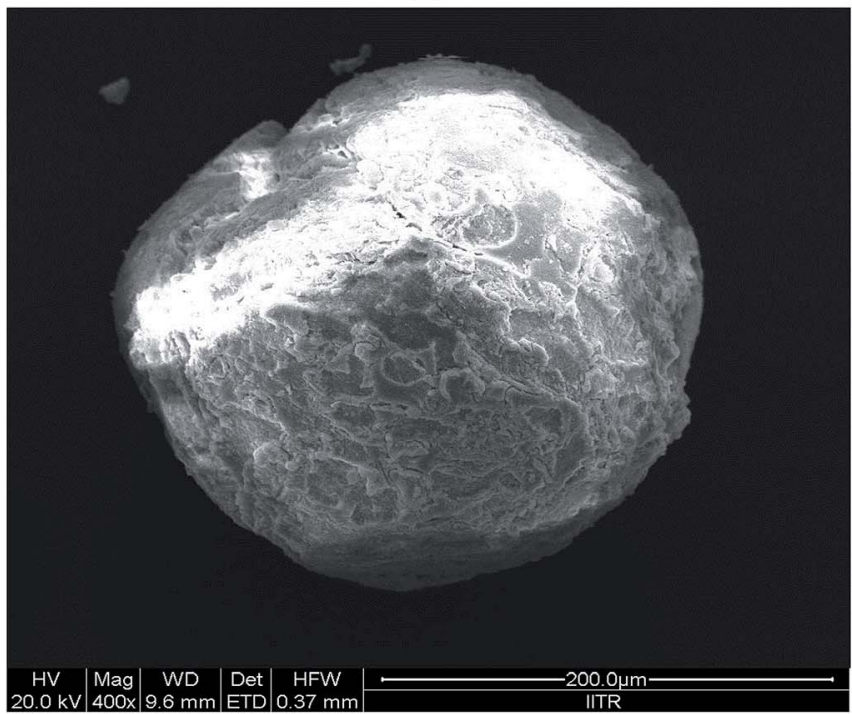

(c)

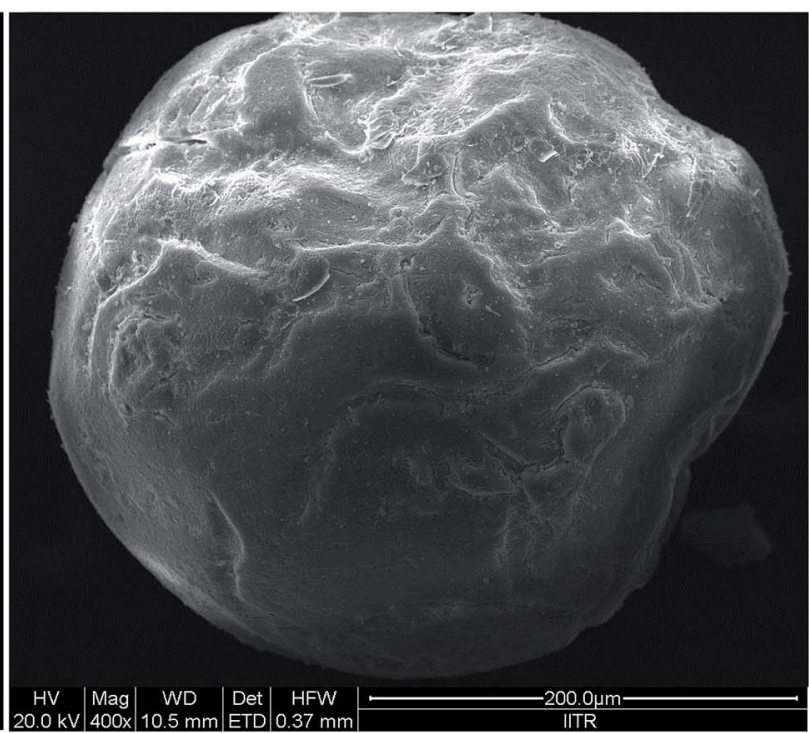

(b)

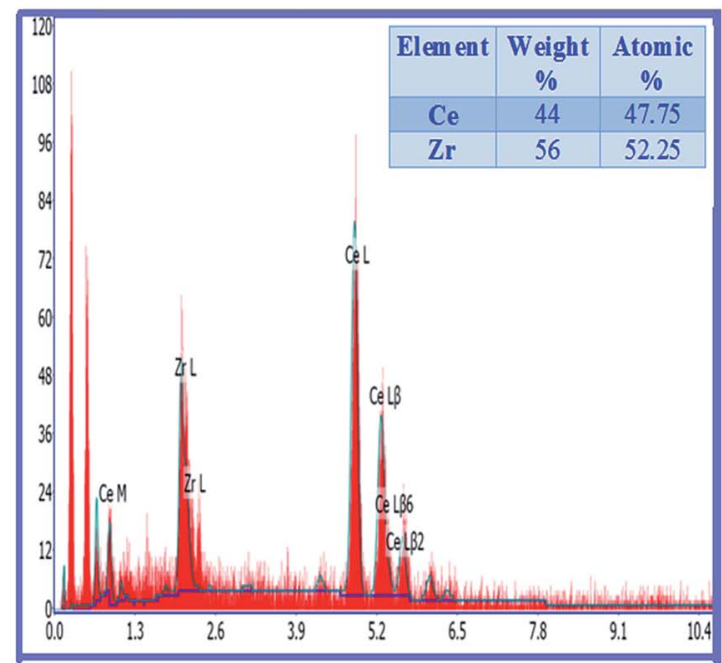

(d)

Fig. 2 FE-SEM images and EDX of (a) $\mathrm{CeO}_{2}$, (b) $\mathrm{ZrO}_{2}$, (c) $\mathrm{Ce}_{0.5} \mathrm{Zr}_{0.5} \mathrm{O}_{2}$, (d) EDX spectra of $\mathrm{Ce}_{0.5} \mathrm{Zr}_{0.5} \mathrm{O}_{2}$. 
distribution in the range of $d_{\mathrm{P}}=0.2-0.4 \mathrm{~mm}$ and the EDX analysis of the $\mathrm{Ce}_{0.5} \mathrm{Zr}_{0.5} \mathrm{O}_{2}$ catalyst are shown in Fig. 2. Analysis has also been carried out by ICP-OES. The structural chemical compositions of the $\mathrm{Ce}_{0.5} \mathrm{Zr}_{0.5} \mathrm{O}_{2}$ and $\mathrm{Ce}_{0.4} \mathrm{Zr}_{0.6} \mathrm{O}_{2}$ catalysts are shown in Table 2 . The compositions of the synthesized catalysts are similar to the desired initial metal composition.

Textural properties. The nitrogen sorption results of ceriumzirconium mixed oxides $\mathrm{Ce}_{x} \mathrm{Zr}_{1-x} \mathrm{O}_{2}(x=0$ to 1 ) are summarized in Table 1. Among all the synthesized catalysts, $\mathrm{Ce}_{0.4} \mathrm{Zr}_{0.6} \mathrm{O}_{2}$ and $\mathrm{Ce}_{0.5} \mathrm{Zr}_{0.5} \mathrm{O}_{2}$ were found to possess highest BET surface area of 123 and $121 \mathrm{~m}^{2} \mathrm{~g}^{-1}$ and minimum pore diameter of 11.9 and $10.0 \mathrm{~nm}$, respectively. It can be seen from Fig. 3 , that the specific surface area of the mixed oxides is a function of the $\mathrm{CeO}_{2}$ content in the synthesized catalyst. Adsorption/desorption isotherm and the pore volume distribution of $\mathrm{CeO}_{2}$, $\mathrm{Ce}_{0.5} \mathrm{Zr}_{0.5} \mathrm{O}_{2}, \mathrm{ZrO}_{2}$ are shown in Fig. $4 \mathrm{a}$ and $\mathrm{b}$, respectively. All the sorption isotherms are of type IV isotherm with the hysteresis loop, typical of mesoporous systems. ${ }^{50,51}$ Peak corresponding to maximum pore volume shifts towards higher pore width for mixed Ce-Zr oxide as compared to pure $\mathrm{CeO}_{2}$ or $\mathrm{ZrO}_{2}$. Mixed oxides exhibit specific surface areas between $112 \mathrm{~m}^{2} \mathrm{~g}^{-1}$ (pure zirconia) and $28 \mathrm{~m}^{2} \mathrm{~g}^{-1}$ (pure ceria). With an increase in the content of ceria, the specific surface area of the mixed oxide decreased and the average pore diameter increased with an increase in the ceria content, with the exception of the mixed oxides with $x=0.4-0.5$ i.e. $\mathrm{Ce}_{0.4} \mathrm{Zr}_{0.6} \mathrm{O}_{2}$ and $\mathrm{Ce}_{0.5} \mathrm{Zr}_{0.5} \mathrm{O}_{2}$ (Fig. 3). These two catalysts exhibit specific surface area $>120 \mathrm{~m}^{2} \mathrm{~g}^{-1}$ with the mean pore diameter of $\sim 10 \mathrm{~nm}$. At these values of $x$, the cause of increase in surface area is the formation of structurally homogeneous solid solution. ${ }^{52,53}$ Laosiripojana et al. ${ }^{54}$ showed the specific surface area of 49,47 , and $46.5 \mathrm{~m}^{2} \mathrm{~g}^{-1}$ with the average particle size of $50-80 \mathrm{~nm}$ using Ce/Zr molar ratio of $1 / 3,1 / 1$, and $3 / 1$, respectively. Shotipruk et al. ${ }^{55}$ showed the specific surface area of 135,120 , and $115 \mathrm{~m}^{2} \mathrm{~g}^{-1}$ with Ce/Zr molar ratio $1 / 3,1 / 1$, and $3 / 1$, respectively and Laosiripojana and Assabumrungrat, ${ }^{56}$ shows $\approx 20 \mathrm{~m}^{2} \mathrm{~g}^{-1}$ with $5 \% \mathrm{Ni}$ on $\mathrm{Ce} / \mathrm{Zr}$ molar ratio $1 / 3,1 / 1$, and $3 / 1$, respectively.

$\mathbf{C O}_{2}$-TPD. The basic properties of $\mathrm{CeO}_{2}, \mathrm{Ce}_{0.5} \mathrm{Zr}_{0.5} \mathrm{O}_{2}$ and $\mathrm{ZrO}_{2}$ catalysts were determined from the $\mathrm{CO}_{2}$-TPD profile (Fig. 5a) and the results are given in Table 3. Basic properties of the catalysts depend upon the temperature profile in the weak region $\left(<200{ }^{\circ} \mathrm{C}\right)$, moderate region $\left(200-450^{\circ} \mathrm{C}\right)$ and the strong region $\left(>450{ }^{\circ} \mathrm{C}\right)$. Weak basic sites are due to the interaction between the surface and the $\mathrm{OH}$ groups and the formation of bicarbonate; moderate basic sites are due to the sites $\mathrm{M}^{x+}-\mathrm{O}^{2-}$

Table 2 Elemental analysis of $\mathrm{Ce}_{0.5} \mathrm{Zr}_{0.5} \mathrm{O}_{2}$ and $\mathrm{Ce}_{0.4} \mathrm{Zr}_{0.6} \mathrm{O}_{2}$ catalysts

\begin{tabular}{|c|c|c|c|c|c|}
\hline \multirow[b]{2}{*}{ Catalysts } & \multicolumn{2}{|c|}{$\begin{array}{l}\text { Nominal } \\
\text { value of } \\
\text { metals }\end{array}$} & \multicolumn{2}{|c|}{$\begin{array}{l}\text { Actual values } \\
\text { of metals } \\
\text { from ICP-OES } \\
\text { analysis }\end{array}$} & \multirow[b]{2}{*}{ Chemical formula } \\
\hline & $\mathrm{Ce}$ & $\mathrm{Zr}$ & $\mathrm{Ce}$ & $\mathrm{Zr}$ & \\
\hline $\mathrm{Ce}_{0.5} \mathrm{Zr}_{0.5} \mathrm{O}_{2}$ & 0.5 & 0.5 & 0.48 & 0.52 & $\mathrm{Ce}_{0.48} \mathrm{Zr}_{0.52} \mathrm{O}_{2}$ \\
\hline $\mathrm{Ce}_{0.4} \mathrm{Zr}_{0.6} \mathrm{O}_{2}$ & 0.4 & 0.6 & 0.39 & 0.61 & $\mathrm{Ce}_{0.39} \mathrm{Zr}_{0.61} \mathrm{O}_{2}$ \\
\hline
\end{tabular}

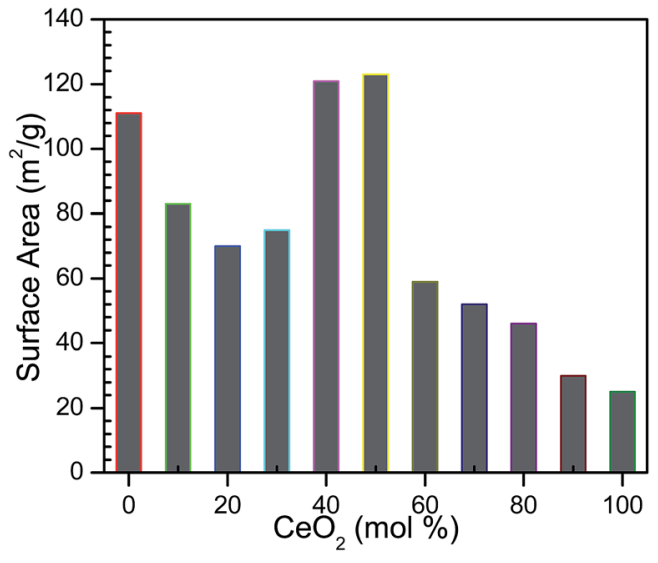

Fig. 3 Surface area of the $\mathrm{Ce}_{x} \mathrm{Zr}_{1-x} \mathrm{O}_{2}$ mixed oxides from the synthesis depending on the $\mathrm{CeO}_{2}$-content.

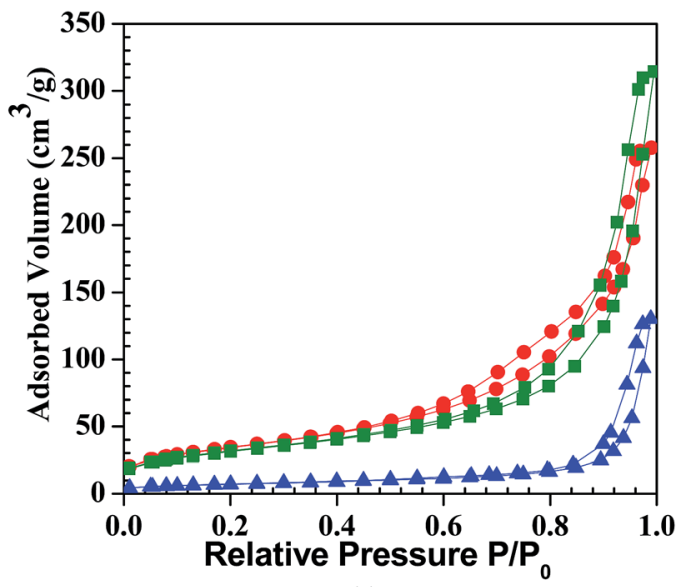

(a)

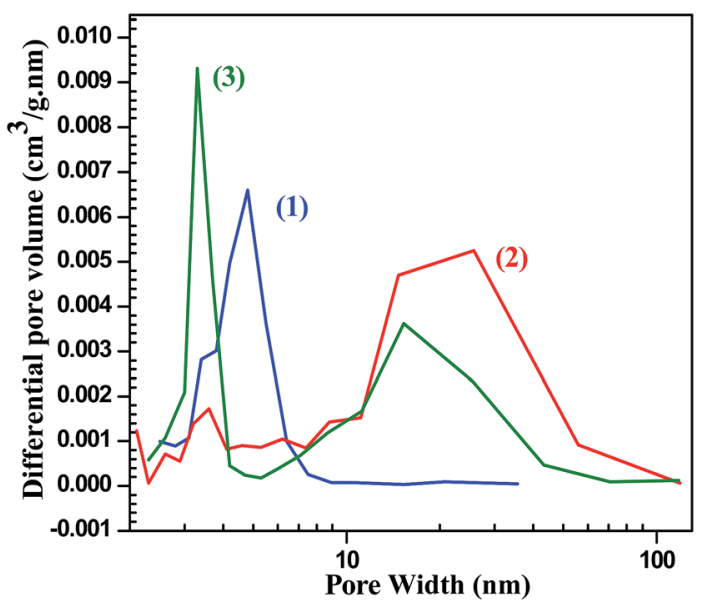

(b)

Fig. 4 (a) $\mathrm{N}_{2}$ adsorption/desorption isotherm $\mathrm{CeO}_{2}, \mathrm{Ce}_{0.5} \mathrm{Zr}_{0.5} \mathrm{O}_{2}$, $\mathrm{ZrO}_{2}$; $-\boldsymbol{-}-\mathrm{ZrO}_{2},-\bullet-\mathrm{Ce}_{0.5} \mathrm{Zr}_{0.5} \mathrm{O}_{2},-\boldsymbol{\Delta}-\mathrm{CeO}_{2}$. (b) Pore diameter distributions of $\mathrm{CeO}_{2}, \mathrm{Ce}_{0.5} \mathrm{Zr}_{0.5} \mathrm{O}_{2}, \mathrm{ZrO}_{2}$. (1) $\mathrm{CeO}_{2}$, (2) $\mathrm{Ce}_{0.5} \mathrm{Zr}_{0.5} \mathrm{O}_{2}$, and (3) $\mathrm{ZrO}_{2}$

pairs and the formation of bi-dentate and bridged carbonates; and the strong basic sites are due to the low coordination $\mathrm{O}^{2-}$ ions and the formation of uni-dentate carbonates. ${ }^{57}$ In the 


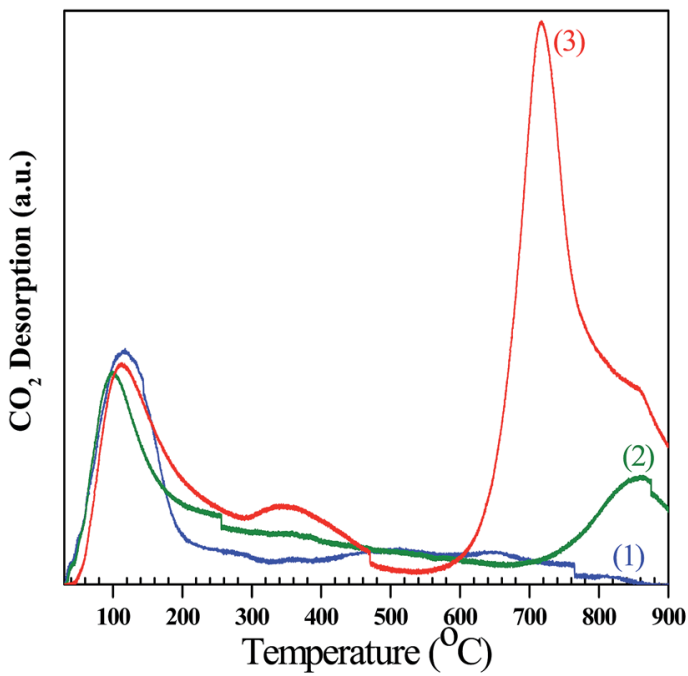

(a)

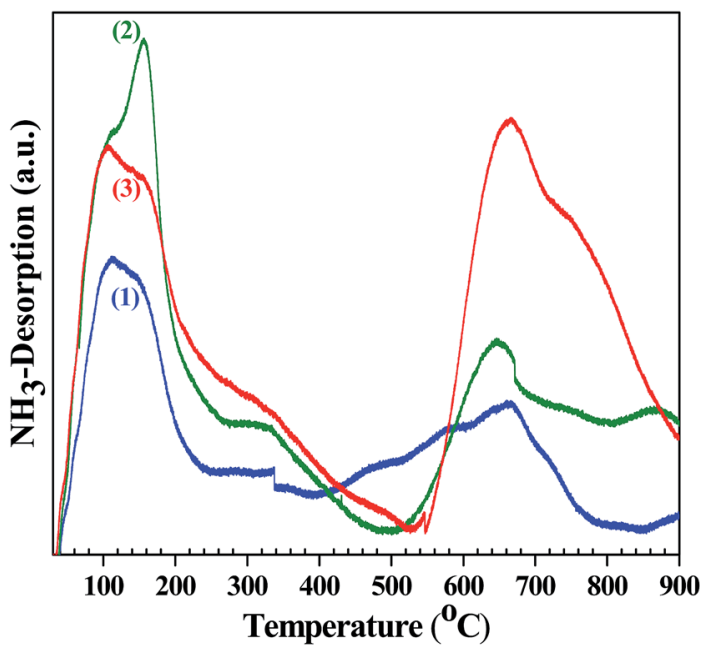

(b)

Fig. 5 (a) $\mathrm{CO}_{2}$-TPD of the synthesized $\mathrm{CeO}_{2}, \mathrm{Ce}_{0.5} \mathrm{Zr}_{0.5} \mathrm{O}_{2}, \mathrm{ZrO}_{2}$ catalysts, (b) $\mathrm{NH}_{3}-\mathrm{TPD}$ of the synthesized $\mathrm{CeO}_{2}, \mathrm{Ce}_{0.5} \mathrm{Zr}_{0.5} \mathrm{O}_{2}, \mathrm{ZrO}_{2}$ catalysts. (1) $\mathrm{CeO}_{2}$, (2) $\mathrm{ZrO}_{2}$, and (3) $\mathrm{Ce}_{0.5} \mathrm{Zr}_{0.5} \mathrm{O}_{2}$. synthesized catalysts, basicity was found in the week and strong regions corresponding to $\sim 115$ and $\sim 717{ }^{\circ} \mathrm{C}$. Basic site density of the synthesized catalysts was in the order: $\mathrm{ZrO}_{2}(0.40 \mathrm{mmol}$ $\left.\mathrm{g}^{-1}\right)<\mathrm{CeO}_{2}\left(0.41 \mathrm{mmol} \mathrm{g}^{-1}\right)<\mathrm{Ce}_{0.5} \mathrm{Zr}_{0.5} \mathrm{O}_{2}\left(1.93 \mathrm{mmol} \mathrm{g}^{-1}\right)$, and the basic site density per unit area followed the same order (Table 3$)$. In ceria catalyst, Ce may have variable valency $\left(\mathrm{Ce}^{3+}\right.$ and $\mathrm{Ce}^{4+}$ ). Moreover, ceria is also a typical Lewis-base catalyst, which is responsible for its application in several basecatalyzing processes. Thus, the mixed metal oxides possess higher basic site density as compared to single oxide catalysts. ${ }^{33}$ Zhang et $a .^{16}$ and Lee et $a l .{ }^{17}$ reported maximum basic site density of 0.276 and $0.017 \mathrm{mmol} \mathrm{g}^{-1}$, respectively, for $\mathrm{Ce}_{0.6} \mathrm{Zr}_{0.4} \mathrm{O}_{2}$ catalysts.

$\mathbf{N H}_{3}$-TPD. $\mathrm{NH}_{3}$-TPD spectra of $\mathrm{CeO}_{2}, \mathrm{Ce}_{0.5} \mathrm{Zr}_{0.5} \mathrm{O}_{2}$ and $\mathrm{ZrO}_{2}$ catalysts are shown in Fig. $5 \mathrm{~b}$ and the results are summarized in Table 3. Desorption peaks of $\mathrm{NH}_{3}$ are in the temperature range of 50-900 ${ }^{\circ} \mathrm{C}$. The $\mathrm{NH}_{3}$ desorption peaks at $110{ }^{\circ} \mathrm{C}$ and $667^{\circ} \mathrm{C}$ for $\mathrm{CeO}_{2}$ and at $156{ }^{\circ} \mathrm{C}$ and $643{ }^{\circ} \mathrm{C}$ for $\mathrm{ZrO}_{2}$ were observed in the week and strong regions. $\mathrm{Ce}_{0.5} \mathrm{Zr}_{0.5} \mathrm{O}_{2}$ catalyst shows peaks in all the three regions at $106{ }^{\circ} \mathrm{C}, 294{ }^{\circ} \mathrm{C}$ and $666{ }^{\circ} \mathrm{C}$. Acidic site density of synthesized catalysts is found to be: $\mathrm{CeO}_{2}(0.94 \mathrm{mmol}$ $\left.\mathrm{g}^{-1}\right)<\mathrm{ZrO}_{2}\left(1.52 \mathrm{mmol} \mathrm{g}{ }^{-1}\right)<\mathrm{Ce}_{0.5} \mathrm{Zr}_{0.5} \mathrm{O}_{2}\left(2.48 \mathrm{mmol} \mathrm{g}{ }^{-1}\right)$. Thus, the $\mathrm{Ce}_{0.5} \mathrm{Zr}_{0.5} \mathrm{O}_{2}$ catalyst has the highest acidic site density and the $\mathrm{CeO}_{2}$ has the lowest acidic site density. Thus, the $\mathrm{Ce}_{0.5} \mathrm{Zr}_{0.5} \mathrm{O}_{2}$ catalyst has the highest density of basic and acidic sites as compared to other catalysts. Therefore, this catalyst can act as an acid-base bi-functional catalyst. It has been reported that both the basic and acidic sites are required for the direct conversion of $\mathrm{CO}_{2}$ to produce DMC. ${ }^{16,17,20}$

\section{Catalytic activity of catalysts for DMC synthesis}

The direct catalytic conversion of $\mathrm{CO}_{2}$ with methanol for the synthesis of DMC was studied in the presence of $\mathrm{CeO}_{2}, \mathrm{ZrO}_{2}$ and $\mathrm{Ce}_{0.5} \mathrm{Zr}_{0.5} \mathrm{O}_{2}$ catalysts. Negligible conversion of $\mathrm{CO}_{2} /$ methanol to DMC after for $24 \mathrm{~h}$ at $120{ }^{\circ} \mathrm{C}$ temperature and 150 bar pressure were observed in the blank experiment without any catalyst. In the presence of a $\mathrm{Ce}_{0.5} \mathrm{Zr}_{0.5} \mathrm{O}_{2}$ catalyst, methanol is activated to

Table 3 TPD analysis using absorbed $\mathrm{CO}_{2}$ and $\mathrm{NH}_{3}$ for determining basic and acidic properties of $\mathrm{CeO}_{2}, \mathrm{Ce}_{0.5} \mathrm{Zr}_{0.5} \mathrm{O}_{2}$ and $\mathrm{ZrO}_{2}{ }^{a}$

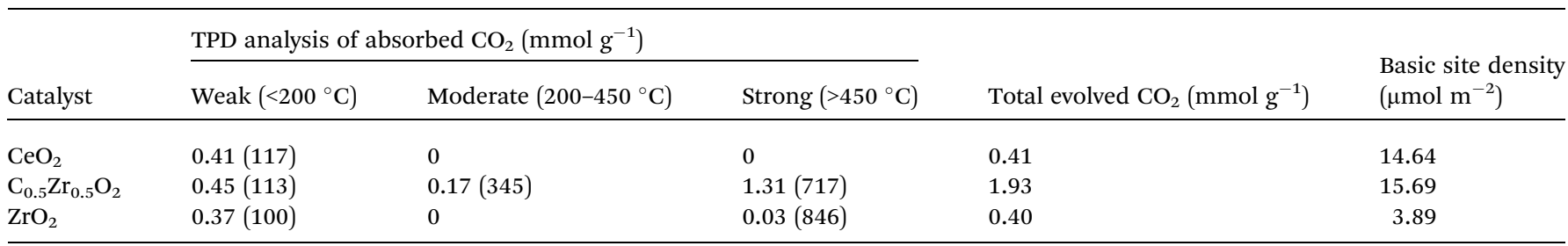

\begin{tabular}{lllll}
\hline & \multicolumn{2}{l}{ TPD analysis of absorbed $\mathrm{NH}_{3}\left(\mathrm{mmol} \mathrm{g}^{-1}\right)$} & & Strong $\left(>450{ }^{\circ} \mathrm{C}\right)$ \\
\cline { 2 - 5 } Catalyst & Weak $\left(<200{ }^{\circ} \mathrm{C}\right)$ & Moderate $\left(200-450{ }^{\circ} \mathrm{C}\right)$ & $\begin{array}{l}\text { Total evolved NH } \\
\left.(\mathrm{mmol} \mathrm{g})^{-1}\right)\end{array}$ \\
\hline $\mathrm{CeO}_{2}$ & $0.81(110)$ & 0 & $0.13(667)$ & 0.94 \\
$\mathrm{C}_{0.5} \mathrm{Zr}_{0.5} \mathrm{O}_{2}$ & $0.99(106)$ & $0.27(294)$ & $1.49(666)$ & 2.48 \\
$\mathrm{ZrO}_{2}$ & $1.31(156)$ & 0 & $0.21(643)$ & 1.52
\end{tabular}

${ }^{a}$ Temperature $\left({ }^{\circ} \mathrm{C}\right)$ at maxima is given in brackets. 


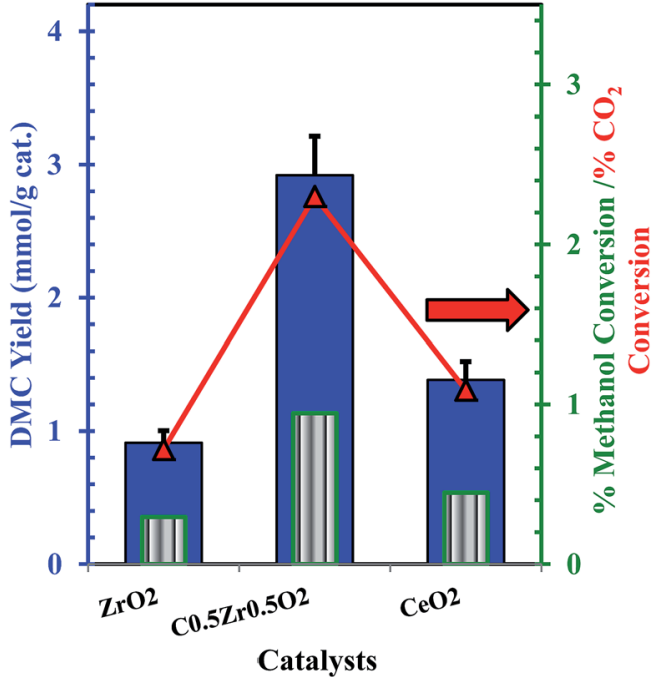

Fig. 6 (a) Methanol conversion and $\mathrm{DMC}$ yield over $\mathrm{CeO}_{2}$, $\mathrm{Ce}_{0.5} \mathrm{Zr}_{0.5} \mathrm{O}_{2}$ and $\mathrm{ZrO}_{2}$ catalysts; reaction conditions: (methanol = $25.03 \mathrm{~mL}$, catalyst dose $=1.25 \mathrm{~g}, P=150 \mathrm{bar}, T=120^{\circ} \mathrm{C}, t=24 \mathrm{~h}$ ); $\square$ DMC yield ( $\mathrm{mmol} \mathrm{g}^{-1}$ cat.), In \% methanol conversion, $-\mathbf{\Delta -} \% \mathrm{CO}_{2}$ conversion.

form $\mathrm{CH}_{3} \mathrm{O}^{-}$and $\mathrm{H}^{+}$in the presence of basic sites and $\mathrm{CH}_{3}{ }^{+}$and $\mathrm{OH}^{-}$in the presence of acidic site present on the surface of the catalyst. Methoxy species $\left(\mathrm{CH}_{3} \mathrm{O}^{-}\right)$react with $\mathrm{CO}_{2}$ in the presence of basic site to form methoxyl carbonyl ions. Methanol is activated at the acidic site to form $\mathrm{CH}_{3}{ }^{+}$and $\mathrm{OH}^{-}$ions. Methoxyl carbonyl ion reacts with $\mathrm{CH}_{3}{ }^{+}$to form DMC, and $\mathrm{OH}^{-}$reacts with $\mathrm{H}^{+}$to form water (Fig. 6). As such, higher basicity and acidity in the catalysts facilitate DMC synthesis from $\mathrm{CO}_{2}$ and methanol. ${ }^{44}$ Reaction mechanism for DMC synthesis from the direct conversion of $\mathrm{CO}_{2}$ with methanol in the presence of the catalyst is shown in Fig. 7. $\mathrm{Ce}_{0.5} \mathrm{Zr}_{0.5} \mathrm{O}_{2}$ catalyst showed better activity as compared to $\mathrm{CeO}_{2}$, and $\mathrm{ZrO}_{2}$ (Fig. 7). The order of the activity of the catalysts followed: $\mathrm{ZrO}_{2}(0.912 \mathrm{mmol}$ DMC per $\mathrm{g}$ cat.) $<\mathrm{CeO}_{2}$ (1.384 mmol DMC per g cat.) $<\mathrm{Ce}_{0.5} \mathrm{Zr}_{0.5} \mathrm{O}_{2}$ (2.921 mmol DMC per g cat.). Best active $\mathrm{Ce}_{0.5} \mathrm{Zr}_{0.5} \mathrm{O}_{2}$ catalyst was further used for the optimization of the reaction conditions such as reaction temperature, catalyst dose and reaction time for $\mathrm{CO}_{2}$ conversion.

The influences of reaction time for DMC synthesis in the presence of $\mathrm{Ce}_{0.5} \mathrm{Zr}_{0.5} \mathrm{O}_{2}$ catalyst is shown in Fig. 8a. It can be seen from Fig. 8a that the DMC formation (1.989-2.921 mmol $\mathrm{g}^{-1}$ cat.), methanol conversion (0.644-0.945\%) and $\mathrm{CO}_{2}$ conversion (1.567-2.310\%) increased with an increase in the reaction time up to $24 \mathrm{~h}$. Further increase in the reaction time

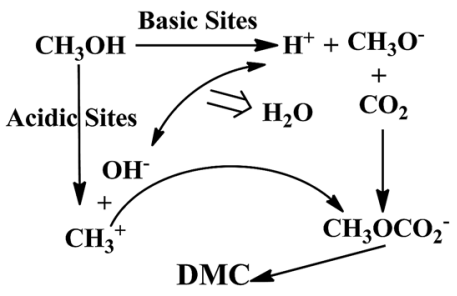

Fig. 7 Mechanism of DMC synthesis from direct conversion of $\mathrm{CO}_{2}$ and methanol. showed a decrease in the DMC yield and $\mathrm{CO}_{2} /$ methanol conversion. It may be because of the saturation of the molecular sieves due to the adsorption of water.

The effect of catalyst dose on the DMC yield and the $\mathrm{CO}_{2}$ conversion is shown in Fig. 8b. It can be seen that the maximum DMC yield and $\mathrm{CO}_{2}$ conversion were obtained at a catalyst dose of $1.25 \mathrm{~g}$. Further increase in the catalyst dose diminished the DMC yield. This may be because of the formation of agglomerates at higher catalyst doses in the reaction mixture.

The influence of the reaction temperature for the DMC synthesis and $\mathrm{CO}_{2} /$ methanol conversion is shown in Fig. 8c. Initially, the DMC yield (1.021-2.9212 $\mathrm{mmol} \mathrm{g}^{-1}$ cat.), methanol conversion (0.331-0.945 mmol g${ }^{-1}$ cat.) and $\mathrm{CO}_{2}$ conversion (0.804-2.300 $\mathrm{mmol} \mathrm{g}^{-1}$ cat.) increased with an increase in the reaction temperature in the range of $80-120{ }^{\circ} \mathrm{C}$. Above $120{ }^{\circ} \mathrm{C}$, an increase in the reaction temperature quickly decreased the DMC yield (2.125-0.8924 $\mathrm{mmol} \mathrm{g}^{-1}$ cat.), methanol conversion (0.687-0.2888 mmol g${ }^{-1}$ cat.) and the $\mathrm{CO}_{2}$ conversion (1.673$0.7026 \mathrm{mmol} \mathrm{g}^{-1}$ cat.). Thus, the optimum DMC yield was obtained at $120^{\circ} \mathrm{C}$. The decrease in the DMC yield, methanol and $\mathrm{CO}_{2}$ conversions may be because of the poor solubility of $\mathrm{CO}_{2}$ in methanol and also due to decomposition of DMC. ${ }^{58}$

It can be seen that the acidic and basic properties directly influence the catalytic activity of DMC synthesis. The reuse of the $\mathrm{Ce}_{0.5} \mathrm{Zr}_{0.5} \mathrm{O}_{2}$ catalyst was investigated at optimum reaction conditions $\left(T=120^{\circ} \mathrm{C}, t=24 \mathrm{~h}\right.$ and catalyst amount $\left.=1.25 \mathrm{~g}\right)$ in five consecutive batch cycles (Fig. 9). Almost similar DMC yield was found in all the batch cycles. Thus, the $\mathrm{Ce}_{0.5} \mathrm{Zr}_{0.5} \mathrm{O}_{2}$ catalyst is found to be an effective catalyst with long life and can be used in a number of cycles.

\section{Chemical equilibrium modeling}

Synthesis of DMC from direct conversion of $\mathrm{CO}_{2}$ and methanol can be related to the equilibrium constant as shown below:

$$
\begin{aligned}
K_{\mathrm{eq}}(T)= & \frac{a_{\mathrm{DMC} a_{\mathrm{H}_{2} \mathrm{O}}}}{a_{\mathrm{MeOH}^{2} a_{\mathrm{CO}_{2}}}} \\
= & \frac{\frac{1}{2} X_{\mathrm{eq}, \mathrm{MeOH}}{ }^{2}\left(1-0.5 y_{\mathrm{MeOH}, 0} X_{\mathrm{eq}, \mathrm{MeOH}}\right)}{y_{\mathrm{MeOH}, 0}\left(1-X_{\mathrm{eq}}\right)^{2}\left(\Theta_{\mathrm{CO}_{2}}-\frac{1}{2} X_{\mathrm{eq}}\right)} \\
& \times\left(\frac{\varphi_{\mathrm{DMC} \varphi_{\mathrm{H}_{2} \mathrm{O}}}}{\left(\varphi_{\mathrm{MeOH}}\right)^{2} \varphi_{\mathrm{CO}_{2}}}\right)_{\mathrm{eq}}\left(\frac{\left(\varphi_{\mathrm{MeOH}}^{0}\right)^{2} \varphi_{\mathrm{CO}_{2}}^{0}}{\varphi_{\mathrm{DMC}}^{0} \varphi_{\mathrm{H}_{2} \mathrm{O}}^{0}}\right)\left(\frac{P^{0}}{P}\right)
\end{aligned}
$$

where, $\Theta_{\mathrm{CO}_{2}}=y_{\mathrm{CO}_{2}, \mathrm{O}} / y_{\mathrm{MeOH}, 0}$.

The Peng-Robinson-Stryjek-Vera equation of state (PRSVEoS) ${ }^{59}$ along with the van der Waals one-fluid (1PVDW) mixing rule, ${ }^{60,61}$ were used to calculate the fugacity coefficient of species in the mixture. PRSV-EoS is given as:

$$
P=\frac{R T}{V-b}-\frac{a \alpha(T)}{V(V+b)+b(V-b)}
$$

where,

$$
\begin{gathered}
a=0.45724 R^{2} T_{\mathrm{c}}{ }^{2} / P_{\mathrm{c}} \\
b=0.0778 R T_{\mathrm{c}} / P_{\mathrm{c}}
\end{gathered}
$$




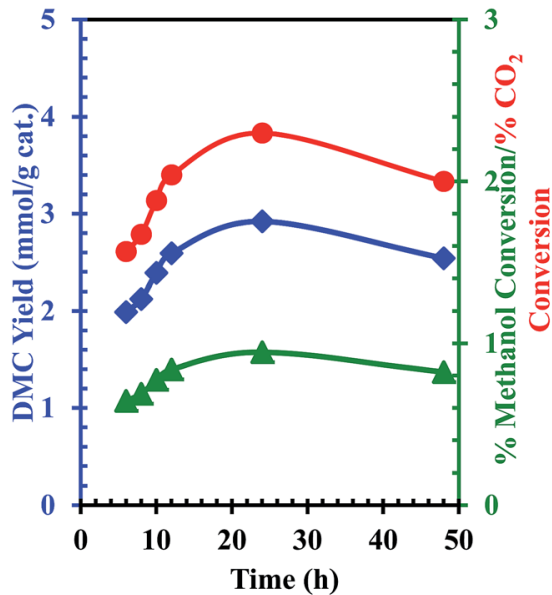

(a)

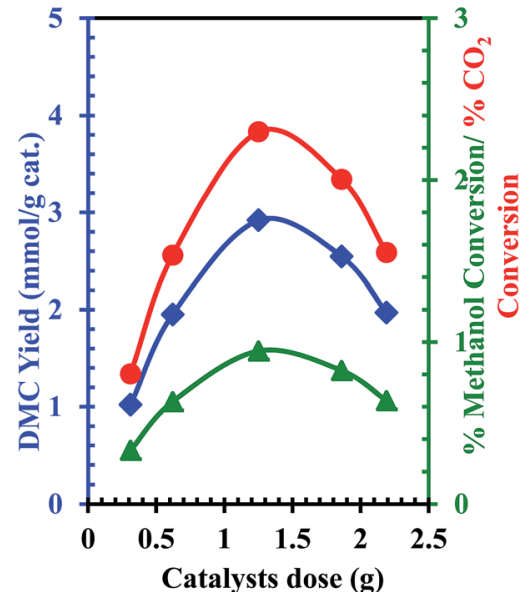

(b)

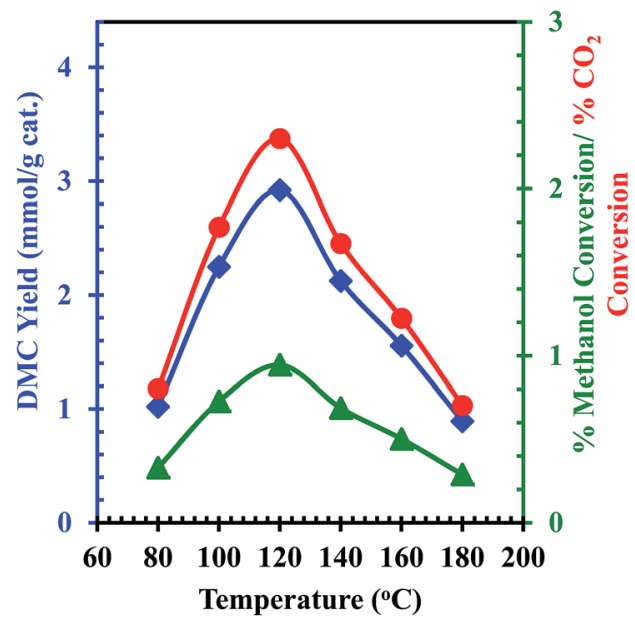

(c)

Fig. 8 Effect of various parameters for direct conversion of $\mathrm{CO}_{2}$ with methanol for DMC synthesis; (a) effect of reaction time at methanol = $25.03 \mathrm{~mL}$, catalyst dose $=1.25 \mathrm{~g}, P=150 \mathrm{bar}, T=120^{\circ} \mathrm{C}$; (b) effect of catalyst dose at Methanol $=25.03 \mathrm{~mL}, P=150 \mathrm{bar}, T=120{ }^{\circ} \mathrm{C}, t=24 \mathrm{~h} ;(\mathrm{c})$ effect of temperature at methanol $=25.03 \mathrm{~mL}$, catalyst dose $=1.25 \mathrm{~g}, P=150$ bar. $\longrightarrow-\mathrm{CO}_{2}$ conversion, $\longrightarrow \downarrow-\mathrm{DMC}$ yield, $-\mathbf{\Delta}-$ methanol conversion.

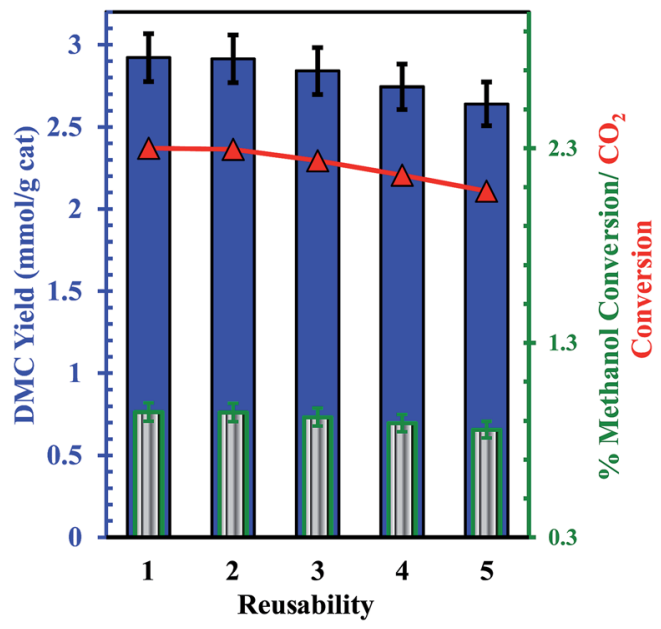

Fig. 9 Reusability of $\mathrm{Ce}_{0.5} \mathrm{Zr}_{0.5} \mathrm{O}_{2}$ catalyst DMC synthesis from direct conversion of $\mathrm{CO}_{2}$ with methanol (methanol $=25.03 \mathrm{~mL}$, catalyst dose $=1.25 \mathrm{~g}, P=150$ bar, $\left.T=120^{\circ} \mathrm{C}, t=24 \mathrm{~h}\right) ; \square \mathrm{DMC}$ yield $\left(\mathrm{mmol} \mathrm{g}{ }^{-1}\right.$ cat.), $\mathbf{I} \mathbf{1 1} \%$ methanol conversion, $-\mathbf{\Delta}-\% \mathrm{CO}_{2}$ conversion.

$$
\begin{gathered}
\alpha=\left[1+m(\omega)\left(1-T_{\mathrm{r}}{ }^{1 / 2}\right)\right]^{2} \\
m(\omega)=\kappa_{0}+\kappa_{1}\left(1+T_{\mathrm{r}}{ }^{1 / 2}\right)\left(0.7-T_{\mathrm{r}}\right) \\
\kappa_{0}=0.378893+1.4897153 \omega-0.1713184 \omega^{2}+0.0196554 \omega^{3}
\end{gathered}
$$

where, $P_{\mathrm{c}}$ and $T_{\mathrm{c}}$ are the critical pressure and temperature, respectively, $\kappa$ is a specific pure compound parameter and $\omega$ is the acentric factor. The values of $T_{\mathrm{c}}, P_{\mathrm{c}}, \omega$ and $\kappa$ as obtained from the literature are compiled in Table S1. $\dagger$ van der Waals one-fluid model (1PVDW) gives the following sets of equations which were used to obtain data of the quadratic mixture:

$$
\begin{gathered}
a=\sum_{i} \sum_{j} y_{i} y_{j}\left(1-k_{i j}\right)\left(a_{i} a_{j}\right)^{1 / 2} \\
b=\sum_{i} \sum_{j} y_{i} y_{j}\left(1-l_{i j}\right)\left(\frac{b_{i}+b_{j}}{2}\right)
\end{gathered}
$$




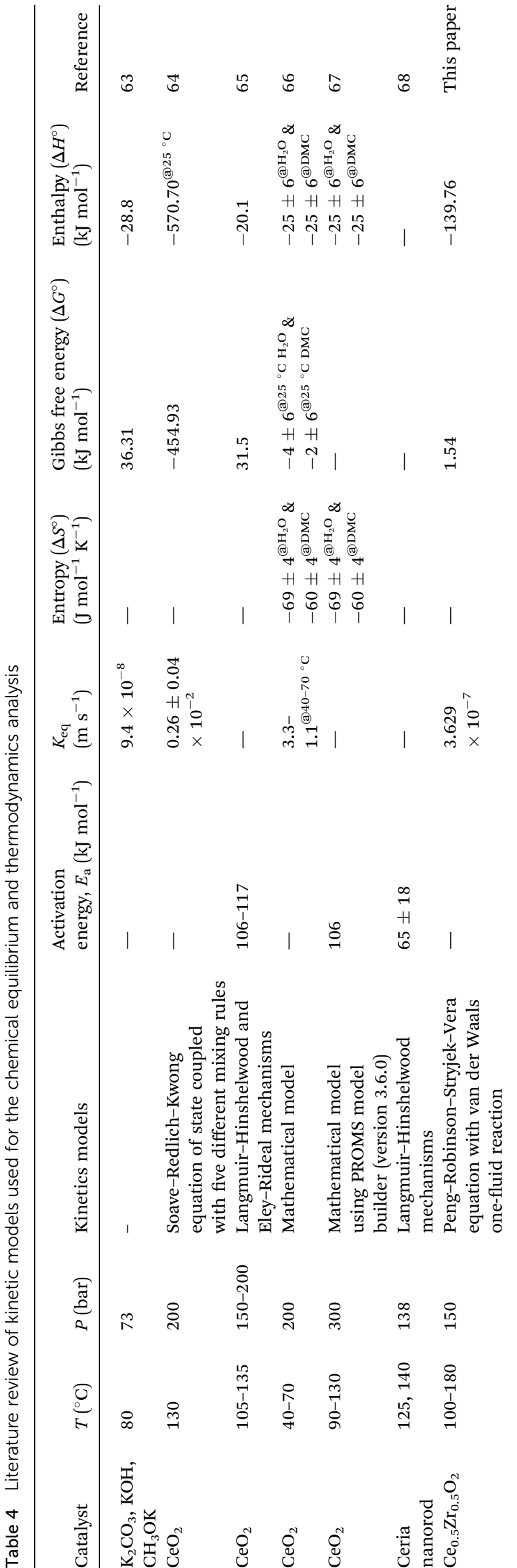

where, $l_{i j}$ and $k_{i j}$ are the single binary interaction parameters, which are used to determine the mixture parameters $a$, and $b$ in the PRSV-EOS. Values of $l_{i j}$ and $k_{i j}$ were obtained from the literature and are given in Table S2. $\dagger$ Assuming that the heat of reaction $\Delta H_{\mathrm{r}}^{\circ}$ is constant within the temperature range of 100$180{ }^{\circ} \mathrm{C}$, the equilibrium constant $K_{\text {eq }}$ can be related to $T$ by the classical van't Hoff equation:

$$
\ln K_{\mathrm{eq}, T}=-\frac{\Delta H_{\mathrm{r}}^{\circ}}{R T}+\left(\frac{\Delta H_{\mathrm{r}}^{\circ}-\Delta G_{\mathrm{r}}^{\circ}}{R T^{\circ}}\right)
$$

Eqn (1)-(9) were solved simultaneously using the parameters given in the Tables $\mathrm{S} 1$ and $\mathrm{S} 2 \uparrow$ to calculate the values of $K_{\mathrm{eq}}$ at various temperatures. The values $K_{\mathrm{eq}}$ at 373, 393, 413, 433 and $453 \mathrm{~K}$ were found to be $6.811 \times 10^{-8}, 3.629 \times 10^{-7}, 1.713 \times$ $10^{-7}, 1.823 \times 10^{-8}$ and $1.327 \times 10^{-9} \mathrm{~L} \mathrm{~mol}^{-1}$, respectively (Table S3 $\dagger$ ). The values of $\Delta H_{\mathrm{r}}^{\circ}$ and $\Delta G_{\mathrm{r}}^{\circ}$ (using eqn (10)) for $\mathrm{Ce}_{0.5} \mathrm{Zr}_{0.5} \mathrm{O}_{2}$ using the data points at $T=120-180{ }^{\circ} \mathrm{C}$ were found to be $-139.76 \mathrm{~kJ} \mathrm{~mol}^{-1}$ and $1.54 \mathrm{~kJ} \mathrm{~mol}^{-1}$, respectively. $\Delta H_{\mathrm{r}}^{\circ}$ and $\Delta G_{\mathrm{r}}^{\circ}$ values of $-15.259 \mathrm{~kJ} \mathrm{~mol}^{-1}$ and $29.583 \mathrm{~kJ} \mathrm{~mol}^{-1}$, respectively have been reported in the literature. ${ }^{62}$ Table 4 compares the equilibrium, kinetic and thermodynamic parameters as obtained in the present study with those reported in the literature. ${ }^{6-68}$ It seems that a direct comparison of these parameters for different catalysts is not possible as these were prepared using different methods and evaluated under different operating conditions.

\section{Conclusions}

In this paper, porous and spherically shaped cerium-zirconium catalysts $\left(\mathrm{Ce}_{x}-\mathrm{Zr}_{1-x} \mathrm{O}_{2}\right)$ with different molar ratios were synthesized using an exo- and endo-templating method using PBSAC as exo-template, and Pluronic F-127 as endo-template. XRD pattern showed the reflexes of cubic phase in $\mathrm{CeO}_{2}$, tetragonal phase in $\mathrm{ZrO}_{2}$ and $\mathrm{Ce}_{0.5} \mathrm{Zr}_{0.5} \mathrm{O}_{2}$. The synthesized catalysts showed BET surface between 28-112 $\mathrm{m}^{2} \mathrm{~g}^{-1}$ and pore volume in the range of $0.2-0.42 \mathrm{~cm}^{3} \mathrm{~g}^{-1}$. An increase in the ceria content was found to decrease the specific surface area of the mixed oxides except for $x=0.4-0.5$. At these values of $x$, formation of structurally homogeneous solid solution increased the surface area. These catalysts were tested for direct conversion of $\mathrm{CO}_{2}$ with methanol for the production DMC in a batch reactor. The $\mathrm{Ce}_{x}-\mathrm{Zr}_{1-x}(x=0.5)$ catalyst was found to posses highest amount of basic and acidic sites among all the catalysts, and gave highest DMC yield. At optimized condition (pressure $=150$ bar, temperature $=120{ }^{\circ} \mathrm{C}$, reaction time $=24 \mathrm{~h}$, catalysts dose $=1.25 \mathrm{~g}$ ), the activity of the catalysts was in the following order: $\mathrm{ZrO}_{2}$ (0.912 mmol DMC per g cat.) < $\mathrm{CeO}_{2}$ (1.384 mmol DMC per $\mathrm{g}$ cat.) $<\mathrm{Ce}_{0.5} \mathrm{Zr}_{0.5} \mathrm{O}_{2}$ (2.921 mmol DMC per g cat.). During five consecutive reuse cycles of $\mathrm{Ce}_{0.5} \mathrm{Zr}_{0.5} \mathrm{O}_{2}$ catalyst, only marginal change in DMC yield and methanol conversion was observed. The values of $\Delta H_{\mathrm{r}}^{\circ}$ and $\Delta G_{\mathrm{r}}^{\circ}$ for $\mathrm{Ce}_{0.5} \mathrm{Zr}_{0.5} \mathrm{O}_{2}$ catalyst were found to be $-139.76 \mathrm{~kJ} \mathrm{~mol}^{-1}$ and $1.54 \mathrm{~kJ} \mathrm{~mol}^{-1}$, respectively. 


\section{Acknowledgements}

One of the authors, namely Praveen Kumar, is thankful to Deutscher Akademischer Austausch Dienst (DAAD), Germany, for providing financial support to carry out this work under a Sandwich Model Scholarship.

\section{References}

1 M. A. Pacheco and C. L. Marshall, Review of dimethyl carbonate (DMC) manufacture and its characteristics as a fuel additive, Energy Fuels, 1997, 11, 2-29.

2 N. Keller, G. Rebmann and V. Keller, Catalysts, mechanisms and industrial processes for the dimethyl carbonate synthesis, J. Mol. Catal. A: Chem., 2010, 317, 1-18.

3 B. A. V. Santos, V. M. T. M. Silva, J. M. Loureiro and A. E. Rodrigues, Review for the direct synthesis of dimethyl carbonate, ChemBioEng Rev., 2014, 1, 214-229.

4 P. Kumar, V. C. Srivastava and I. M. Mishra, Dimethyl carbonate synthesis from propylene carbonate with methanol using Cu-Zn-Al catalyst, Energy Fuels, 2015, 29, 2664-2675.

5 P. Zhang, S. Wang, S. Chen, Z. Zhang and X. Ma, The effects of promoters over $\mathrm{PdCl}_{2}-\mathrm{CuCl}_{2} / \mathrm{HMS}$ catalysts for the synthesis of diethyl carbonate by oxidative carbonylation of ethanol, Chem. Eng. J., 2008, 143, 220-224.

6 Z. Zhang, X. Ma, P. Zhang, Y. Li and S. Wang, Effect of treatment temperature on the crystal structure of activated carbon supported $\mathrm{PdCl}_{2}-\mathrm{CuCl}_{2}$ catalysts in the oxidative carbonylation of ethanol to diethyl carbonate, J. Mol. Catal. A: Chem., 2007, 266, 202-206.

7 B. Yan, S. Huang, Q. Meng, Y. Shen, S. Wang and X. Ma, Ordered mesoporous carbons supported wacker-type catalyst for catalytic oxidative carbonylation, AIChE J., 2013, 59, 3797-3805.

8 R. Razzaq, C. Li, N. Amin, S. Zhang and K. Suzuki, Comethanation of carbon oxides over nickel-based $\mathrm{Ce}_{x} \mathrm{Zr}_{1-x} \mathrm{O}_{2}$ catalysts, Energy Fuels, 2013, 27, 6955-6961.

9 C. Li, X. Zhang and S. Zhang, Environmental benign design of DMC production process, Chem. Eng. Res. Des., 2006, 84, 1-8.

10 H. Y. Zeng, X. Deng, Y. J. Wang and K. B. Liao, Preparation of $\mathrm{Mg}-\mathrm{Al}$ hydrotalcite by urea method and its catalytic activity for transesterification, AIChE J., 2009, 55, 1229-1235.

11 S. Xu, H. Y. Zeng, C. R. Xheng, H. Z. Duan, J. Han, P. X. Ding and G. F. Xiao, Mg-Fe mixed oxides as solid base catalysts for the transesterification of microalgae oil, RSC Adv., 2015, 5, 71278-71286.

12 H. Y. Zeng, S. Xu, M. C. Liao, Z. Q. Zhang and C. Zhao, Activation of reconstructed $\mathrm{Mg} / \mathrm{Al}$ hydrotalcites in the transesterification of microalgae oil, Appl. Clay Sci., 2014, 91-92, 16-24.

13 M. Honda, M. Tamura, Y. Nakagawa and K. Tomishige, Catalytic $\mathrm{CO}_{2}$ conversion to organic carbonates with alcohols in combination with dehydration system, Catal. Sci. Technol., 2014, 4, 2830-2845.
14 S. Wang, H. Shen, S. Fan, Y. Zhao, X. Ma and J. Gong, Enhanced $\mathrm{CO}_{2}$ adsorption capacity and stability using CaO-based adsorbents treated by hydration, AIChE J., 2013, 59, 3586-3593.

15 P. Svec, R. Olejník, Z. Padelková, A. Ruzicka and L. Plasseraud, C,N-chelated organotin(Iv) trifluoromethanesulfonates: Synthesis, characterization and preliminary studies of its catalytic activity in the direct synthesis of dimethyl carbonate from methanol and $\mathrm{CO}_{2}, \mathrm{~J}$. Organomet. Chem., 2012, 708-709, 82-87.

16 Z. F. Zhang, Z. T. Liu, Z. W. Liu and J. Lu, DMC formation over $\mathrm{Ce}_{0.5} \mathrm{Zr}_{0.5} \mathrm{O}_{2}$ prepared by complex-decomposition method, Catal. Lett., 2009, 129, 428-436.

17 H. J. Lee, W. Joe and I. K. Song, Direct synthesis of dimethyl carbonate from methanol and carbon dioxide over transition metal oxide/ $\mathrm{Ce}_{0.6} \mathrm{Zr}_{0.4} \mathrm{O}_{2}$ catalysts: Effect of acidity and basicity of the catalysts, Korean J. Chem. Eng., 2012, 29, 317-322.

18 Y. Ikeda, T. Sakaihori, K. Tomishige and K. Fujimoto, Promoting effect of phosphoric acid on zirconia catalysts in selective synthesis of dimethyl carbonate from methanol and carbon dioxide, Catal. Lett., 2000, 66, 59-62.

19 V. Eta, P. Maki-Arvela, A. R. Leino, K. Kordas, T. Salmi, D. Y. Murzin and J. P. Mikkola, Synthesis of dimethyl carbonate from methanol and carbon dioxide: Circumventing thermodynamic limitations, Ind. Eng. Chem. Res., 2010, 49, 9609-9617.

20 L. Chen, S. Wang, J. Zhou, Y. Shen, Y. Zhao and X. Ma, Dimethyl carbonate synthesis from carbon dioxide and methanol over $\mathrm{CeO}_{2}$ versus over $\mathrm{ZrO}_{2}$ : comparison of mechanisms, RSC Adv., 2014, 4, 30968-30975.

21 P. Kumar, P. With, V. C. Srivastava, R. Gläser and I. M. Mishra, Conversion of carbon dioxide along with methanol to dimethyl carbonate over ceria catalyst, $J$. Environ. Chem. Eng., 2015, 3, 2943-2947.

22 J. Bian, M. Xiao, S. Wang, X. Wang, Y. Lu and Y. Meng, Highly effective synthesis of dimethyl carbonate from methanol and carbon dioxide using a novel copper nickel/ graphite-bimetallic nanocomposite catalyst, Chem. Eng. J., 2009, 147, 287-296.

23 Y. Zhou, S. Wang, M. Xiao, D. Han, Y. Lu and Y. Meng, Novel $\mathrm{Cu}-\mathrm{Fe}$ bimetal catalyst for the formation of dimethyl carbonate from carbon dioxide and methanol, RSC Adv., 2012, 2, 6831-6837.

24 P. Kumar, P. With, V. C. Srivastava, R. Gläser and I. M. Mishra, Efficient ceria-zirconium oxide catalyst for carbon dioxide conversions: characterization, catalytic activity and thermodynamic study, J. Alloys Compd., DOI: 10.1016/j.jallcom.2016.10.293.

25 Z. F. Zhang, Z. T. Liu, Z. W. Liu and J. Lu, DMC formation over $\mathrm{Ce}_{0.5} \mathrm{Zr}_{0.5} \mathrm{O}_{2}$ prepared by complex-decomposition method, Catal. Lett., 2009, 129, 428-436.

26 H. J. Lee, W. Joe and I. K. Song, Direct synthesis of dimethyl carbonate from methanol and carbon dioxide over transition metal oxide/ $\mathrm{Ce}_{0.6} \mathrm{Zr}_{0.4} \mathrm{O}_{2}$ catalysts: Effect of acidity and basicity of the catalysts, Korean J. Chem. Eng., 2012, 29, 317-322. 
27 M. Aresta, A. Dibenedetto, C. Pastore, A. Angelini, B. Aresta and I. Pápai, Influence of $\mathrm{Al}_{2} \mathrm{O}_{3}$ on the performance of $\mathrm{CeO}_{2}$ used as catalyst in the direct carboxylation of methanol to dimethylcarbonate and the elucidation of the reaction mechanism, J. Catal., 2010, 269, 44-52.

28 V. Eta, P. Mäki-Arvela, E. Salminen, T. Salmi, D. Y. Murzin and J. P. Mikkola, The Effect of alkoxide ionic liquids on the synthesis of dimethyl carbonate from $\mathrm{CO}_{2}$ and methanol over $\mathrm{ZrO}_{2}-\mathrm{MgO}$, Catal. Lett., 2011, 141, 1254-1261.

29 D. Ballivet-Tkatchenko, S. Chambrey, R. Keiski, R. Ligabue, L. Plasseraud, P. Richard and H. Turunen, Direct synthesis of dimethyl carbonate with supercritical carbon dioxide: Characterization of a key organotin oxide intermediate, Catal. Today, 2006, 115, 80-87.

30 L. Allaoui and A. Aouissi, Effect of the Bronsted acidity on the behavior of $\mathrm{CO}_{2}$ methanol reaction, J. Mol. Catal. A: Chem., 2006, 259, 281-285.

31 Q. Cai, B. Lu, L. Guo and Y. Shan, Studies on synthesis of dimethyl carbonate from methanol and carbon dioxide, Catal. Commun., 2009, 10, 605-609.

32 H. J. Lee, S. Park, J. C. Jung and I. K. Song, Direct synthesis of dimethyl carbonate from methanol and carbon dioxide over $\mathrm{H}_{3} \mathrm{PW}_{12} \mathrm{O}_{40} / \mathrm{Ce}_{x} \mathrm{Zr}_{1-x} \mathrm{O}_{2}$ catalysts: Effect of acidity of the catalysts, Korean J. Chem. Eng., 2011, 28, 1518-1522.

33 K. W. La, J. C. Jung, H. Kim, S. H. Baeck and I. K. Song, Effect of acid-base properties of $\mathrm{H}_{3} \mathrm{PW}_{12} \mathrm{O}_{40} / \mathrm{Ce}_{x} \mathrm{Ti}_{1-x} \mathrm{O}_{2}$ catalysts on the direct synthesis of dimethyl carbonate from methanol and carbon dioxide: A TPD study of $\mathrm{H}_{3} \mathrm{PW}_{12} \mathrm{O}_{40}$ / $\mathrm{Ce}_{x} \mathrm{Ti}_{1-x} \mathrm{O}_{2}$ catalysts, J. Mol. Catal. A: Chem., 2007, 269, 4145.

34 M. Sheintuch and Y. I. Matatov-Meytal, Comparison of catalytic processes with other regeneration methods of activated carbon, Catal. Today, 1999, 53, 73-80.

35 U. Matatov-Meytal and M. Sheintuch, Activated carbon clothsupported $\mathrm{Pd}-\mathrm{Cu}$ catalyst: Application for continuous water denitrification, Catal. Today, 2005, 102-103, 121-127.

36 P. Kumar, P. With, V. C. Srivastava, R. Gläser and I. M. Mishra, Glycerol carbonate synthesis by hierarchically structured catalysts: catalytic activity and characterization, Ind. Eng. Chem. Res., 2015, 54, 2543-12552.

37 P. With, A. Heinrich, M. Lutecki, S. Fichtner, B. Böhringer and R. Gläser, Zirconia with defined particle morphology and hierarchically structured pore system synthesized via combined exo- and endo-templating, Chem. Eng. Technol., 2010, 33, 1712-1716.

38 M. Epifani, T. Andreu, S. Abdollahzadeh-Ghom, J. Arbiol and J. R. Morante, Synthesis of ceria-zirconia nanocrystals with improved microstructural homogeneity and oxygen storage capacity by hydrolytic sol-gel process in coordinating environment, Adv. Funct. Mater., 2012, 22, 2867-2875.

39 P. Bharali, P. Saikia, L. Katta and B. M. Reddy, Enhancement in $\mathrm{CO}$ oxidation activity of nanosized $\mathrm{Ce}_{x} \mathrm{Zr}_{1-x} \mathrm{O}_{2}$ solid solutions by incorporation of additional dopants, J. Ind. Eng. Chem., 2013, 19, 327-336.

40 H. Zhu, R. Razzaq, C. Li, Y. Muhmmad and S. Zhang, Catalytic methanation of carbon dioxide by active oxygen material $\mathrm{Ce}_{x} \mathrm{Zr}_{1-x} \mathrm{O}_{2}$ supported $\mathrm{Ni}-\mathrm{Co}$ bimetallic nanocatalysts, AIChE J., 2013, 59, 2567-2576.

41 A. S. Deshpande and M. Niederberger, Synthesis of mesoporous ceria zirconia beads, Microporous Mesoporous Mater., 2007, 101, 413-418.

42 T. X. T. Satyle, S. C. Parker and C. R. A. Catlow, Surface segregation of metal ions in cerium dioxide, J. Phys. Chem., 1994, 98, 13625-13630.

43 L. Wu, S. Dey, M. Gong, F. Liu and R. H. R. Castro, Surface segregation on manganese doped ceria nanoparticles and relationship with nanostability, J. Phys. Chem. C, 2014, 118, 30187-30196.

44 J. P. Jacobs, A. Maltha, J. G. H. Reintjes, J. Drimal, V. Ponec and $\mathrm{H}$. H. Brongersma, The surface of catalytically active spinels, J. Catal., 1994, 147, 294-300.

45 Z. Sun, X. Wang, Z. Liu, H. Zhang, P. Yu and L. Mao, Pt-Ru/ $\mathrm{CeO}_{2}$ /Carbon nanotube nanocomposites: An efficient electrocatalyst for direct methanol fuel cells, Langmuir, 2010, 26, 12383-12389.

46 L. Wang, Y. Wang, S. Liu, L. Lu, X. Ma and Y. Deng, Efficient synthesis of dimethyl carbonate via transesterification of ethylene carbonate with methanol over binary zinc-yttrium oxides, Catal. Commun., 2011, 16, 45-49.

47 B. D. Rivas, R. López-Fonseca, M. A. Gutiérrez-Ortiz and J. I. Gutiérrez-Ortiz, Structural characterisation of $\mathrm{Ce}_{0.5} \mathrm{Zr}_{0.5} \mathrm{O}_{2}$ modified by redox treatments and evaluation for chlorinated VOC oxidation, Appl. Catal., B, 2011, 101, 317-325.

$48 \mathrm{~S}$. Y. Christou and A. M. Efstathiou, The effects of Ppoisoning of $\mathrm{Ce}_{x} \mathrm{Zr}_{1-x} \mathrm{O}_{2}$ on the transient oxygen storage and release kinetics, Top. Catal., 2013, 56, 232-238.

49 W. Wang, S. Wang, X. Ma and J. Gong, Crystal structures, acid-base properties, and reactivities of $\mathrm{Ce}_{x} \mathrm{Zr}_{1-x} \mathrm{O}_{2}$ catalysts, Catal. Today, 2009, 148, 323-328.

$50 \mathrm{H}$. Abir and M. Sheintuch, Atomistic calculation of adsorption in activated carbon with pore-size distribution, J. Colloid Interface Sci., 2010, 342, 445-454.

51 M. Taubert, J. Beckmann, A. Lange, D. Enke and O. Klepel, Attempts to design porous carbon monoliths using porous concrete as a template, Microporous Mesoporous Mater., 2014, 197, 58-62.

52 R. O. Fuentes and R. T. Baker, Synthesis of nanocrystalline $\mathrm{CeO}_{2}-\mathrm{ZrO}_{2}$ solid solutions by a citrate complexation route: A thermochemical and structural study, J. Phys. Chem. C, 2009, 113, 914-924.

53 Y. Li, L. Wang, R. Yan, J. Hana and S. Zhang, Gold nanoparticles supported on $\mathrm{Ce}-\mathrm{Zr}$ oxides for the oxidative esterification of aldehydes to esters, Catal. Sci. Technol., 2015, 5, 3682-3692.

54 N. Laosiripojana, K. Kiatkittipong and S. Assabumrungrat, Partial oxidation of palm fatty acids over $\mathrm{Ce}-\mathrm{ZrO}_{2}$ : Roles of catalyst surface area, lattice oxygen capacity and mobility, AIChE J., 2011, 57, 2861-2869.

55 A. Shotipruk, S. Assabumrungrat, P. Pavasant and N. Laosiripojana, Reactivity of $\mathrm{CeO}_{2}$ and $\mathrm{Ce}-\mathrm{ZrO}_{2}$ toward steam reforming of palm fatty acid distilled (PFAD) with 
co-fed oxygen and hydrogen, Chem. Eng. Sci., 2009, 64, 459466.

56 N. Laosiripojana and S. Assabumrungrat, Methane steam reforming over $\mathrm{Ni} / \mathrm{Ce}-\mathrm{ZrO}_{2}$ catalyst: Influences of $\mathrm{Ce}-\mathrm{ZrO}_{2}$ support on reactivity, resistance toward carbon formation, and intrinsic reaction kinetics, Appl. Catal., A, 2005, 290, 200-211.

57 Z. Liu, Y. Yi, S. Zhang, T. Zhu, J. Zhu and J. Wang, Selective catalytic reduction of $\mathrm{NO}_{x}$ with $\mathrm{NH}_{3}$ over $\mathrm{Mn}$-Ce mixed oxide catalyst at low temperatures, Catal. Today, 2013, 216, 76-81.

58 S. Kumar and S. L. Jain, Polyethylene glycol enfolded $\mathrm{KBr}$ assisted base catalyzed synthesis of dimethyl carbonate from methanol and carbon dioxide, Ind. Eng. Chem. Res., 2014, 53, 15798-15801.

59 R. Stryjek and J. H. Vera, PRSV: An improved PengRobinson equation of state for pure compounds and mixtures, Can. J. Chem. Eng., 1986, 64, 323-333.

60 P. Piñeroa, J. Garcíaa, M. Sokolovab and M. J. Cocero, Modelling of the phase behaviour for the direct synthesis of dimethyl carbonate from $\mathrm{CO}_{2}$ and methanol at supercritical or near critical conditions, J. Chem. Thermodyn., 2007, 39, 536-549.

61 F. Bustamente, A. F. Orrego, S. Villegas and A. L. Villa, Modeling of chemical equilibrium and gas phase behavior for the direct synthesis of dimethyl carbonate from $\mathrm{CO}_{2}$ and methanol, Ind. Eng. Chem. Res., 2012, 51, 8945-8956.

62 P. Kongpanna, V. Pavarajarn, R. Gani and S. Assabumrungrat, Techno-economic evaluation of different $\mathrm{CO}_{2}$-based processes for dimethyl carbonate production, Chem. Eng. Res. Des., 2015, 93, 496-510.

63 Q. Cai, B. Lu, L. Guo and Y. Shan, Studies on synthesis of dimethyl carbonate from methanol and carbon dioxide, Catal. Commun., 2009, 10, 605-609.

64 B. A. V. Santos, V. M. T. M. Silva, J. M. Loureiro, D. Barbosa and A. E. Rodrigues, Modeling of physical and chemical equilibrium for the direct synthesis of dimethyl carbonate at high pressure conditions, Fluid Phase Equilib., 2012, 336, 41-51.

65 B. A. V. Santos, C. S. M. Pereira, V. M. T. M. Silva, J. M. Loureiro and A. E. Rodrigues, Kinetic study for the direct synthesis of dimethyl carbonate from methanol and $\mathrm{CO}_{2}$ over $\mathrm{CeO}_{2}$ at high pressure conditions, Appl. Catal., A, 2013, 455, 219-226.

66 B. A. V. Santos, V. M. T. M. Silva, J. M. Loureiro and A. E. Rodrigues, Adsorption of $\mathrm{H}_{2} \mathrm{O}$ and Dimethyl Carbonate at High Pressure over Zeolite 3A in Fixed Bed Column, Ind. Eng. Chem. Res., 2014, 53, 2473-2483.

67 B. A. V. Santos, C. S. M. Pereira, V. M. T. M. Silva, J. M. Loureiro and A. E. Rodrigues, Design of a true moving bed reactor for the direct synthesis of dimethyl carbonate, Chem. Eng. Sci., 2015, 123, 406-419.

68 C. M. Marin, L. Li, A. Bhalkikar, J. E. Doyle, X. C. Zeng and C. L. Cheung, Kinetic and mechanistic investigations of the direct synthesis of dimethyl carbonate from carbon dioxide over ceria nanorod catalysts, J. Catal., 2016, 340, 295-301. 